Int. J. Electrochem. Sci., 14 (2019) 2160 - 2174

\title{
Numerical Studies of Cell Stack for Zinc-Nickel Single Flow Battery
}

\author{
Shouguang Yao ${ }^{1, *}$, Yunhui Zhao ${ }^{1}$, Xiaofei Sun ${ }^{1}$, Dapei Ding ${ }^{1}$, Jie Cheng ${ }^{2}$ \\ ${ }^{1}$ Jiangsu University of Science and Technology, Zhenjiang 212003, China \\ ${ }^{2}$ Zhangjiagang Smartgrid Fanghua Electrical Energy Storage Research Institute, Zhangjiagang \\ 215600, China \\ *E-mail: zjyaosg@126.com
}

doi: $10.20964 / 2019.03 .80$

Received: 2 November 2018 / Accepted: 26 December 2018 / Published: 7 February 2019

\begin{abstract}
A three-dimensional stationary model is established, based on the universal conservation laws and a kinetic model for reaction involving hydroxide and zinc ions, is applied to describe a zinc-nickel single flow battery cells stack. The model is validated against the experimental data and is used to describe the spatial distribution of flow, concentration, current density and potential. The effects of variations in electrolyte flow rate and concentration are further studied. The model results indicate that the current density and potential distribution of each battery cell have good consistency and the influence of the spatial arrangement of battery cells is more clearly reflected in the distribution of flow and concentration. An increase in flow rate or ions concentration leads to a slighter concentration polarization, a better consistency and a higher cell stack voltage.
\end{abstract}

Keywords: zinc-nickel single flow battery, cell stack, three-dimensional stationary model, concentration polarization, cell stack voltage

\section{FULL TEXT}

(C) 2019 The Authors. Published by ESG (www.electrochemsci.org). This article is an open access article distributed under the terms and conditions of the Creative Commons Attribution license (http://creativecommons.org/licenses/by/4.0/). 